\begin{tabular}{l|l|l|}
\cline { 3 - 3 } CRITICAL & $\begin{array}{l}\text { Western Ghats } \\
\text { EARTNERSHIP FUND }\end{array}$ & Special Series \\
\cline { 2 - 3 } & &
\end{tabular}

\title{
Phylogenetic position and osteology of Pethia setnal (ChHAPGAR \& SANE, 1992), AN ENDEMIC BARB (TELEOSTEI: CYPRINIDAE) OF THE WESTERN GHATS, INDIA, WITH NOTES ON ITS DISTRIBUTION AND THREATS
}

\section{Unmesh Katwate ${ }^{1}$, Mandar S. Paingankar ${ }^{2}$, Shrikant Jadhav ${ }^{3}$ \& Neelesh Dahanukar ${ }^{4}$}

${ }^{1}$ Bombay Natural History Society (BNHS), Hornbill House, Opposite Lion Gate, Shaheed Bhagat Singh Road, Mumbai, Maharashtra 400001, India

${ }^{2,4}$ Systematics, Ecology \& Conservation Laboratory, Zoo Outreach Organization (ZOO), 96 Kumudham Nagar, Villankurichi Road, Coimbatore, Tamil Nadu 641035, India

${ }^{3}$ Zoological Survey of India (ZSI), Western Regional Center, Akurdi, Pune, Maharashtra 411044, India

${ }^{4}$ Indian institute of Science Education and Research (IISER), Dr. Homi Bhabha Road, Pashan, Pune, Maharashtra 411008, India

${ }^{1}$ theunmesh@gmail.com, ${ }^{2}$ mandarpaingankar@gmail.com, ${ }^{3}$ shrikantj123@yahoo.com

${ }^{4}$ n.dahanukar@iiserpune.ac.in (corresponding author)

\begin{abstract}
Pethia setnai is an endemic and threatened freshwater fish of the Western Ghats of India. It has a restricted distribution in the west flowing rivers in the states of Maharashtra, Goa and Karnataka. We clarify the phylogenetic position of Pethia setnai, provide osteological details of topotypic material, and morphometric data of specimens from Maharashtra, Goa and Karnataka. We also provide details on micro-level distribution, habitat and threats to the species in its native range.
\end{abstract}

Keywords: Biometrics, Puntius setnai, threatened, topotype.

DOI: http://dx.doi.org/10.11609/JoTT.03857.5214-27 | ZooBank: urn:Isid:zoobank.org:pub:4F75DBB8-C599-402B-A9D1-C63D5CDD9DE7

Editor: Anonymity requested.

Date of publication: 26 December 2013 (online \& print)

Manuscript details: Ms \# 03857 | Received 21 November 2013 | Final received 17 December 2013 | Finally accepted 18 December 2013

Citation: Katwate, U., M.S. Paingankar, S. Jadhav \& N. Dahanukar (2013). Phylogenetic position and osteology of Pethia setnai (Chhapgar \& Sane, 1992), an endemic barb (Teleostei: Cyprinidae) of the Western Ghats, India, with notes on its distribution and threats. Journal of Threatened Taxa 5(17): 5214-5227; http://dx.doi. org/10.11609/JoTT.03857.5214-27

Copyright: (C) Katwate et al. 2013. Creative Commons Attribution 3.0 Unported License. JoTT allows unrestricted use of this article in any medium, reproduction and distribution by providing adequate credit to the authors and the source of publication.

Funding: Neelesh Dahanukar is a DST-INSPIRE Faculty Fellow. This study was partially supported by DST-INSPIRE Research Grant [IFA12-LSBM-21], Government of India to Neelesh Dahanukar and CEPF-ATREE Western Ghats Small Grant (CEPF-ATREE-WGhats/SGP/WGSG186 - BNHS_FISHES) to Unmesh Katwate.

Competing interests: Declared none. Funding source had no role in study design, data collection, results interpretation and manuscript writing.

Author Contribution: UK, MP and ND collected fresh specimens. UK, SJ and ND studied museum specimens. UK, MP, SJ and ND performed morphometry. UK performed osteology. MP and ND performed genetic analysis. UK, MP, SJ and ND wrote the manuscript.

Acknowledgements, Author Details: see end of this article.
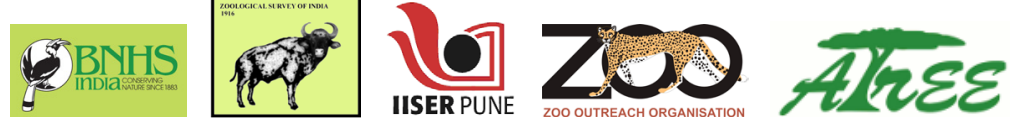

This article forms part of a special series on the Western Ghats of India, disseminating the results of work supported by the Critical Ecosystem Partnership Fund (CEPF), a joint initiative of I'Agence Française de Développement, Conservation International, the European Commission, the Global Environment Facility, the Government of Japan, the MacArthur Foundation and the World Bank. A fundamental goal of CEPF is to ensure civil society is engaged in biodiversity conservation. Implementation of the CEPF investment program in the Western Ghats is led and coordinated by the Ashoka Trust for Research in Ecology and the Environment (ATREE). 


\section{INTRODUCTION}

Two major hurdles in conservation of threatened and endemic species, especially those that occur in biodiversity hotspots is the Wallacean shortfall (arising from the incomplete information regarding the distribution of species) and Linnean shortfall (several species still not formally described) (Bini et al. 2006). The Western Ghats region, part of the Western GhatsSri Lanka biodiversity hotspot is no exception to this, as it has already been suggested that the freshwater fish fauna (especially endemic and threatened species) of this region is poorly known with regard to their taxonomy and distribution (Dahanukar et al. 2011; Raghavan et al. 2012). One reason for this gap in knowledge regarding geographical distribution is the lack of detailed descriptions and reliable genetic data, which can ultimately lead to misidentifications. As a result, genetic sequences from topotypic material and detailed morphometric data will not only help in understanding the systematics of the species, but also provide reliable identification criteria.

In a recent review of the South Asian barbs previously placed under the genus Puntius, Pethiyagoda et al. (2012) tentatively placed Puntius setnai Chhapgar \& Sane, 1992 in the genus Pethia based on the data available in the original description of the species. The tentative placement was probably due to the limited information on the morphology, osteology and/or genetic data of the species. In the current study, we provide genetic information of Pethia setnai from topotypic material, osteological details to confirm the placement of the species under Pethia, and reliable genetic and morphometric data for accurate identification of the species. We also provide information on the distribution, habitat and threats to the species.

\section{MATERIALS AND METHODS}

\section{Study site}

Topotypes of Pethia setnai were collected from Salaulim River, a tributary of Zuari River in Sanguem $\left(15.234^{\circ} \mathrm{N} \& 74.182^{\circ} \mathrm{E}, 19 \mathrm{~m}\right)$, Goa. Additional material was also collected from Terekhol River at Madkhol Village $\left(15.935^{\circ} \mathrm{N} \& 73.910^{\circ} \mathrm{E}, 43 \mathrm{~m}\right)$, Maharashtra (Fig. 1). Collections were done responsibly following the guidelines set by IUCN (2008). Material collected in the present study is deposited in the museum of Bombay Natural History Society (BNHS), Mumbai; Wildlife Information Liaison Development (WILD), Coimbatore, and the Zoological Survey of India, Western Regional Center (ZSI-WRC), Pune.

\section{Morphometry}

Measurements were taken point to point using dial calipers to the nearest $0.01 \mathrm{~mm}$ and then rounded to $0.1 \mathrm{~mm}$. Subunits of the body are presented as percent of standard length (SL), and subunits of the head are presented as percent of head length $(\mathrm{HL})$. All pored scales were counted when reporting the lateral line scales. Methods for taking counts and measurements follow Kullander (2008) and Pethiyagoda et al. (2012).

\section{Materials examined}

Pethia setnai: 9 exs., BNHS FWF 53, 63 to 70, 10.viii.2013, collected from Sanguem, Goa, by U. Katwate, M. Paingankar and N. Dahanukar; 3 exs., WILD13-PIS-043 to 045, 10.viii.2013, collected from Sanguem, Goa, by U. Katwate, M. Paingankar and N. Dahanukar; 2 exs., ZSI-WRC P/3567, 10.viii.2013, collected from Sanguem, Goa, by U. Katwate, M. Paingankar and N. Dahanukar; 9 exs., BNHS FWF 54 to 62, 12.vi.2013, collected from Terekhol River at Madkhol, Maharashtra, by U. Katwate and N. Dahanukar; 3 exs., WILD-13PIS-046 to 48, 12.vi.2013, collected from Terekhol River at Madkhol, Maharashtra, by Unmesh Katwate and Neelesh Dahanukar; 2 exs., ZSI-WRC P/3568, 12.vi.2013, collected from Terekhol River at Madkhol, Maharashtra, by U. Katwate and N. Dahanukar; 1 ex., ZSI-WRC P/3572, 5.ii.1971, collected from Kaneri River at Gund, District Karwar (Mysore), by B.S. Lamba and Party; 3 exs., ZSIWRC P/3571, 17.ii.1971, collected from Ramanguli, District Karwar (Mysore), by B. S. Lamba and Party; 26 exs. BNHS FWF 17-42, collected from Sanguem, Goa by S.R. Sane.

\section{Photographs examined}

Pethia setnai: Holotype, ZSI Kolkata FF2766, 01.iii.1985, collected from Sanguem, Goa, by S.R. Sane; Paratypes, 6 exs., ZSI Kolkata FF2767, 01.iii.1985, collected from Sanguem, Goa, by S.R. Sane.

Pethia narayani: Syntypes, 2 exs., ZSI Kolkata F12180/1, collected from Cauvery River, Coorg, by C.R.N. Rao.

\section{Osteology}

Two specimens (BNHS FWF 55 and BNHS FWF 70) were cleared and stained using the procedure described by Potthoff (1984). Osteological nomenclature follow Conway (2011) and descriptions of osteology follow Pethiyagoda et al. (2012) so as to allow easy comparison 


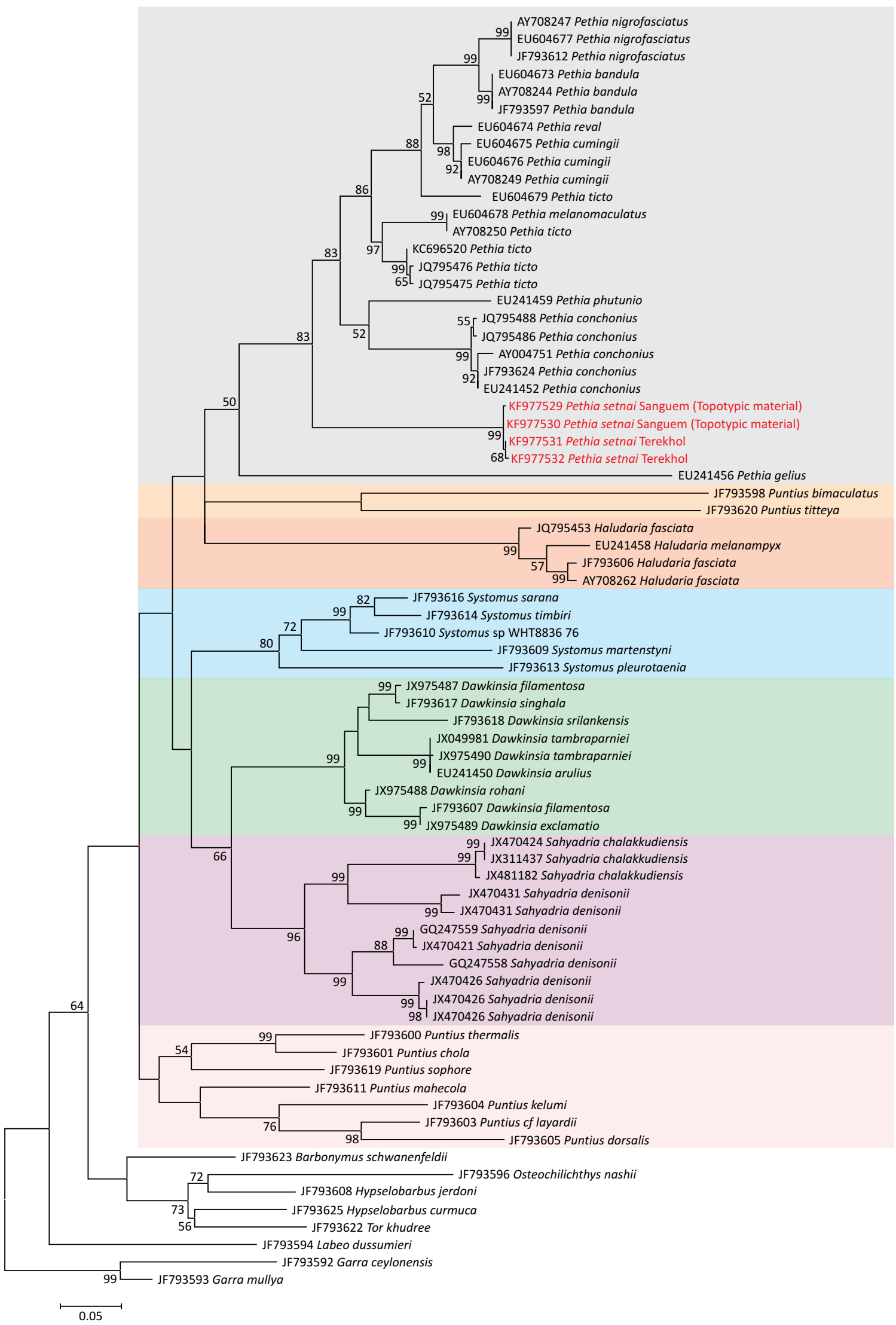

Figure 1. Phylogenetic position of Pethia setnai. Maximum likelihood tree based on mitochondrial cytb gene. Bootstrap support with more than $50 \%$ based on 1000 iterations for maximum likelihood. Garra species are used as outgroup. 
with other related taxa. Osteological illustrations were made from images captured by a digital camera fitted on stereo-zoom light microscope (Leica S8 APO, USA).

\section{Genetic analysis}

Gills were taken from four fresh specimens (BNHS FWF 53, BNHS FWF 54, WILD-13-PIS-043 and WILD13-PIS-046) and preserved in absolute ethanol. The tissue was digested at $60^{\circ} \mathrm{C}$ for two hours using the STE buffer (0.1M NaCl, 0.05M Tris-HCl, 0.01M EDTA, 1\%SDS) with $15 \mu \mathrm{l}$ Proteinase $\mathrm{K}(20 \mathrm{mg} / \mathrm{ml})$ per $500 \mathrm{ml}$ of STE buffer. DNA was extracted using conventional phenolchloroform method and re-suspended in TE $110 \mathrm{mM}$ Tris, $1 \mathrm{mM}$ EDTA, $\mathrm{pH} 8$ ) buffer. Polymerase chain reaction was performed to amplify cytochrome b (cytb) gene using primer pair L14724 (5'-GACTTGAAAAACCACCGTTG-3') and H15915 (5'-CTCCGATCTCCGGATTACAAGAC-3') (Chen et al. 2007). PCR reaction was performed in a $25 \mu$ l reaction volume containing $5 \mu$ l of template DNA ( 200ng), $5 \mu$ l of $10 \mathrm{X}$ reaction buffer (100 mM Tris $\mathrm{pH}$ 9.0, $500 \mathrm{mM} \mathrm{KCl}, 15 \mathrm{mM} \mathrm{MgCl}, 0.1 \%$ Gelatin), $3 \mu \mathrm{l}$ of $25 \mathrm{mM}$ $\mathrm{MgCl}_{2}, 1 \mu \mathrm{l}$ of $10 \mathrm{mM}$ dNTPs, $1 \mu \mathrm{l}$ of each primer, $0.5 \mu \mathrm{l}$ Taq polymerase (2.5 units) and $8.5 \mu \mathrm{l}$ nuclease free water. The thermal profile was 10 minutes at $95^{\circ} \mathrm{C}$, and 35 cycles of 1 minute at $94^{\circ} \mathrm{C}, 1$ minute at $52^{\circ} \mathrm{C}$ and $2 \mathrm{~min}$ at $72^{\circ} \mathrm{C}$, followed by extension of $10 \mathrm{~min}$ at $72^{\circ} \mathrm{C}$. Amplified DNA fragments were purified using the Wizard Gel and PCR clean up system (Promega, USA). The purified PCR products were sequenced using BigDye Terminator v3.1 cycle sequencing kit (Applied Biosystems, USA) and ABI prism 3730 sequencer (Applied Biosystems, USA). Sequences were analyzed by BLAST tool (Altschul et al. 1990). All sequences used in the paper have been deposited in GenBank.

We used the cytb gene dataset of South Asian cyprinid fishes by Pethiyagoda et al. (2012), Raghavan et al. (2013a) and additional sequences of Pethia, Dawkinsia and Haludaria available from NCBI GenBank (http://www.ncbi.nlm.nih.gov/). Accession numbers for the sequences used for the analysis are provided in Fig. 1. Gene sequences were aligned using MUSCLE (Edgar 2004). Phylogeny was performed using the freeware MEGA 5 (Tamura et al. 2011). Best fit model for nucleotide substitution was selected from 24 models available in MEGA 5 based on minimum Akaike Information Criterion (AIC) value (Posada \& Crandall 2001). Tamura \& Nei (1993) nucleotide substitution model including invariant sites and a Gamma parameter was obtained as a best fit model $(\mathrm{TN} 93+\mathrm{G}+\mathrm{I}, \mathrm{AIC}=12894.38, \mathrm{lnL}=-6328.70)$. This model was then used for constructing a phylogenetic tree using the maximum likelihood method. Reliability of the phylogenetic tree was estimated using bootstrap values run for 1000 iterations.

\section{RESULTS AND DISCUSSION}

Before it was formally described, Pethia setnai collected from Ponda, Goa, was first reported as Pethia nigrofasciata (Günther, 1868) by Yazdani (1977). Chhapgar \& Sane (1980) criticized this report, after collecting this species from Sanguem, Goa, as well as examining the specimens studied by Yazdani (1977), and suggested that the species was Pethia narayani (Hora, 1937). However, subsequently, Chhapgar \& Sane (1992) described the species as Puntius setnai. Subsequently, Yazdani \& Ghate (1994) provided further information on this species based on the specimens collected from Hosangadi in Karnataka.

\section{Phylogenetic position}

Pethia setnai forms a monophyletic group (Fig. 1) with the genus Pethia sensu stricto as defined by Pethiyagoda et al. (2012). The genetic divergence in the cytb gene between the topotypic material collected from Sanguem, Goa and additional material collected from Terekhol River at Madkhol, Maharashtra, was $0.325 \%$, while the divergence between the two Terekhol specimens as well as two Sanguem specimens was $0.2 \%$. Because of the very low genetic divergence, the two populations have to be considered as genetically similar. We could not collect fresh specimens of the species for genetic analysis from Karnataka State, and as a result, future studies are essential to establish the extent of genetic variation in different known populations of the species. Nevertheless, as we are providing the genetic information of the topotypic material, future studies can have a more reliable comparative material.

\section{Taxonomy}

Pethia setnai (Chhapgar \& Sane, 1992)

Puntius nigrofasciata (non Günther, 1868): Yazdani (1977)

Puntius narayani (non Hora, 1937): Chhapgar \& Sane (1980)

Puntius setnai Chhapgar \& Sane, 1992: Chhapgar \& Sane (1992), Yazdani \& Ghate (1994), Knight et al. (2012)

Pethia setnai (Chhapgar \& Sane, 1992): Pethiyagoda et al. (2012) 

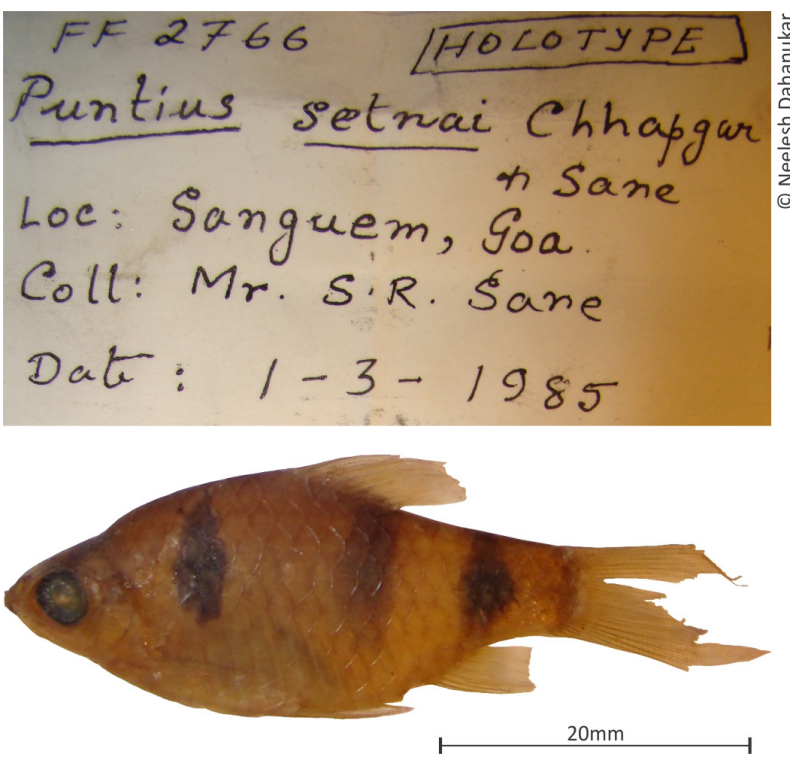

\section{Type material information}

Holotype and six paratypes of Pethia setnai collected from Sanguem, Goa, by S.R. Sane on 1.iii.1985 are available in good condition in the museum collection of ZSI Kolkata under the accession numbers FF2766 (Image 1) and FF2767 (Image 2). Chhapgar \& Sane (1992) described the species based on 25 specimens (the holotype and 24 paratypes) with the note that “... holotype and some of the paratypes will be deposited with the Zoological Survey of India, Calcutta". The whereabouts of remaining 18 paratypes is not known. Interestingly, 26 specimens of $P$. setnai are in the museum collection of BHNS under the accession numbers BNHS FWF 17-42 (see Materials examined). However, whether some of the specimens from BNHS constitute the missing paratypes could not be deciphered.

Image 1. Holotype of Pethia setnai ZSI Kolkata FF 2766
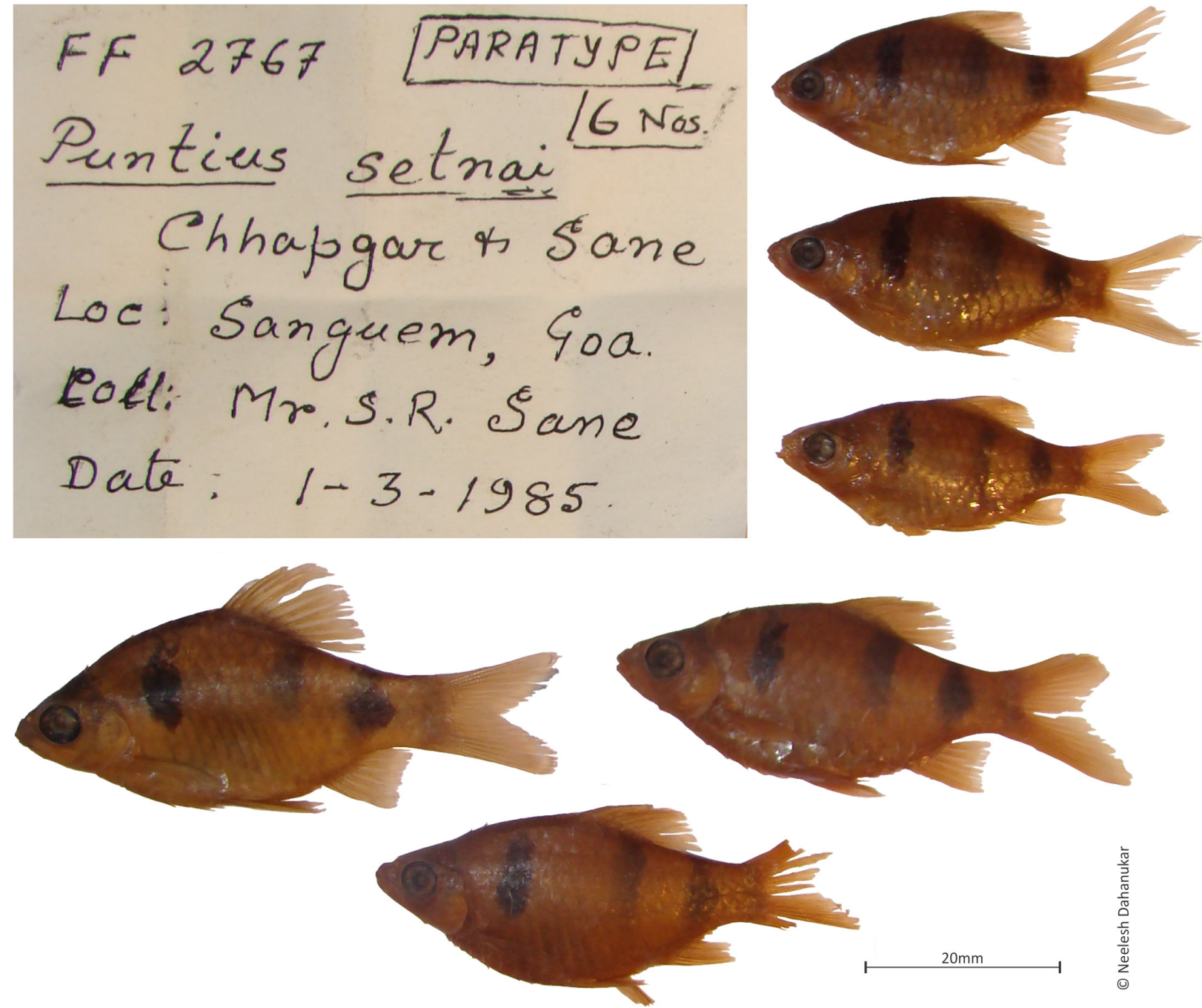

Image 2. Paratypes of Pethia setnai ZSI Kolkata FF 2767 
Table 1. Morphometric characters and meristics of Pethia setnai collected from Sanguem, Madkhol and Karwar. Raw data for all the measurements are provided in Appendix A, B and C.

\begin{tabular}{|c|c|c|c|c|c|c|}
\hline \multirow{2}{*}{ Character } & \multicolumn{2}{|c|}{ Sanguem $(n=12)^{a}$} & \multicolumn{2}{|c|}{ Madkhol $(n=12)^{b}$} & \multicolumn{2}{|c|}{$\operatorname{Karwar}(n=4)^{c}$} \\
\hline & Mean (sd) & Range & Mean (sd) & Range & Mean (sd) & Range \\
\hline Total length (mm) & $42.4(6.0)$ & $34.0-50.4$ & $29.7(4.7)$ & $25.1-42.2$ & $\begin{array}{l}\text { Caudal fin } \\
\text { damaged }\end{array}$ & $\begin{array}{l}\text { Caudal fin } \\
\text { damaged }\end{array}$ \\
\hline Standard length (SL, mm) & $32.6(4.8)$ & $26.3-39.7$ & $23.0(3.6)$ & $19.2-32.4$ & $34.0(3.2)$ & $30.7-37.3$ \\
\hline \multicolumn{7}{|l|}{$\%$ SL } \\
\hline Head length $(\mathrm{HL})$ & $29.9(1.3)$ & $27.7-32.4$ & $29.3(0.9)$ & $27.7-31.0$ & $30.0(2.3)$ & $28.2-33.1$ \\
\hline Head depth & $24.6(0.9)$ & $22.7-25.6$ & $24.6(1.1)$ & $23.0-26.8$ & $22.8(1.0)$ & $21.9-23.8$ \\
\hline Head width & $15.8(0.5)$ & $14.8-16.6$ & $16.5(0.4)$ & $15.6-16.9$ & $16.3(0.2)$ & $16.0-16.5$ \\
\hline Body depth & $40.5(3.0)$ & $35.8-44.4$ & $35.3(1.4)$ & $33.4-38.6$ & $40.9(1.5)$ & $39.1-42.3$ \\
\hline Body width at dorsal fin origin & $16.4(1.1)$ & $14.6-17.7$ & $16.0(1.5)$ & $12.6-18.2$ & $14.5(0.6)$ & $13.7-14.9$ \\
\hline Body width at anal fin origin & $11.9(0.8)$ & $9.9-12.5$ & $12.5(0.9)$ & $11.2-14.9$ & $9.1(0.7)$ & $8.3-9.9$ \\
\hline Pre dorsal distance & $52.5(2.0)$ & $47.1-54.8$ & $52.0(1.8)$ & $49.9-56.6$ & $51.8(4.0)$ & $46.1-55.4$ \\
\hline Dorsal to hypural distance & $47.4(1.6)$ & $43.2-50.1$ & $47.7(2.1)$ & $43.1-49.9$ & $52.2(2.8)$ & $48.8-55.0$ \\
\hline Prepelvic distance & $50.2(2.7)$ & $43.3-53.9$ & $52.7(2.3)$ & $49.4-57.4$ & $48.7(1.4)$ & $47.2-50.6$ \\
\hline Preanal distance & $72.3(2.6)$ & $66.7-76.3$ & $71.5(1.7)$ & $69.2-74.2$ & $71.0(1.4)$ & $69.8-72.6$ \\
\hline Prepectoral distance & $28.4(1.4)$ & $25.6-30.4$ & $31.5(1.3)$ & $29.2-33.8$ & $31.3(2.3)$ & $28.2-33.9$ \\
\hline Dorsal fin length & $26.8(1.7)$ & $24.1-30.1$ & $26.1(1.2)$ & $23.8-27.3$ & $27.4(2.5)$ & $24.8-29.8$ \\
\hline Dorsal fin spine length & $18.9(1.0)$ & $16.8-20.6$ & $17.6(1.0)$ & $15.7-18.9$ & $18.3(2.2)$ & $16.0-20.3$ \\
\hline Length of dorsal fin base & $18.6(1.4)$ & $16.3-20.3$ & $16.9(2.5)$ & $12.0-19.6$ & $19.1(1.4)$ & $17.4-20.3$ \\
\hline Pectoral fin length & $20.7(3.6)$ & $10.0-23.5$ & $18.4(1.4)$ & $16.5-21.4$ & $21.9(3.5)$ & $19.2-27.0$ \\
\hline Anal fin depth & $18.8(1.8)$ & $15.2-21.6$ & $18.6(1.0)$ & $17.1-20.3$ & $19.6(1.2)$ & $18.6-21.3$ \\
\hline Caudal peduncle length & $17.6(1.4)$ & $15.6-19.9$ & $19.3(0.8)$ & $18.3-21.0$ & $16.0(1.2)$ & $15.0-17.6$ \\
\hline Caudal peduncle depth & $15.0(0.4)$ & $14.4-15.5$ & $14.6(1.0)$ & $11.9-15.4$ & $16.1(0.5)$ & $15.5-16.7$ \\
\hline \multicolumn{7}{|l|}{$\% \mathrm{HL}$} \\
\hline Head depth & $82.4(5.6)$ & $69.9-92.2$ & $83.9(4.0)$ & $77.8-90.8$ & $76.5(8.8)$ & $66.3-84.2$ \\
\hline Head width & $52.8(3.4)$ & $46.9-58.3$ & $56.2(2.6)$ & $51.5-60.5$ & $54.7(4.0)$ & $50.0-58.4$ \\
\hline Snout length & $29.8(2.2)$ & $25.2-33.7$ & $27.4(1.8)$ & $24.6-29.9$ & $32.7(2.4)$ & $30.0-35.4$ \\
\hline Eye diameter & $30.2(2.8)$ & $26.7-37.1$ & $34.1(3.0)$ & $27.1-37.6$ & $30.8(2.7)$ & $28.7-34.6$ \\
\hline Inter orbital width & $34.4(4.4)$ & $21.6-39.6$ & $30.2(2.9)$ & $26.2-35.8$ & $37.0(3.3)$ & $33.9-41.6$ \\
\hline
\end{tabular}

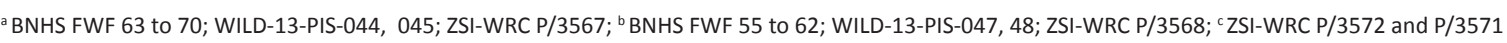

\section{Morphometric and meristic data}

Morphometric characters and meristics of the specimens collected for the present study from the type locality Sanguem, Goa; a newly discovered population from Terekhol River near Madkhol Village, Maharashtra and from Karwar, Karnataka are provided in Table 1 and Table 2, respectively. Photographs specimens collected for the present study are provided in Images 3 and 4 .

\section{Osteology}

Osteology of the specimen from the type locality is provided in Image 5. Gill rakers simple, acuminate (not
Table 2. Range for meristics of Pethia setnai $(n=28)$.

\begin{tabular}{|l|c|}
\hline Meristics & Range \\
\hline Lateral line scales & $19-21$ \\
\hline Transverse scale rows & $\left(3 \frac{1}{2}-4 \frac{1}{2}\right)-1-\left(3-3 \frac{1}{2}\right)$ \\
\hline Predorsal scales & $7-8$ \\
\hline Prepelvic scales & $10-11$ \\
\hline Preanal scales & $14-16$ \\
\hline Dorsal fin rays & iil 8 \\
\hline Pectoral fin rays & i $12 / 13$ \\
\hline Pelvic fin rays & i 7 \\
\hline Anal fin rays & iii 5 \\
\hline
\end{tabular}




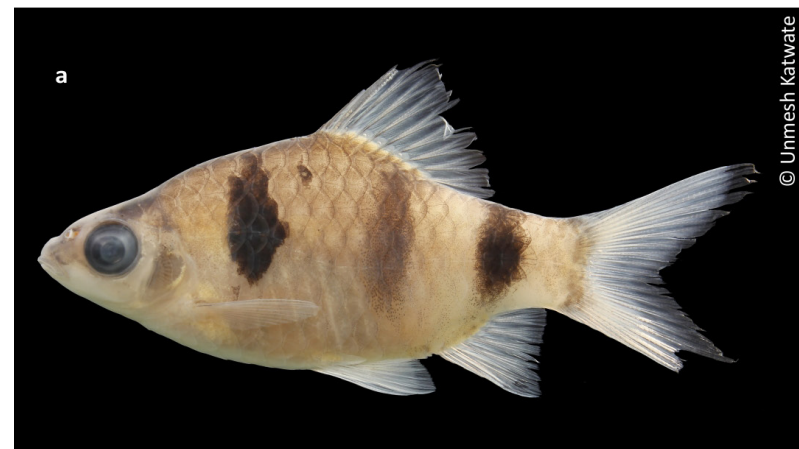

b

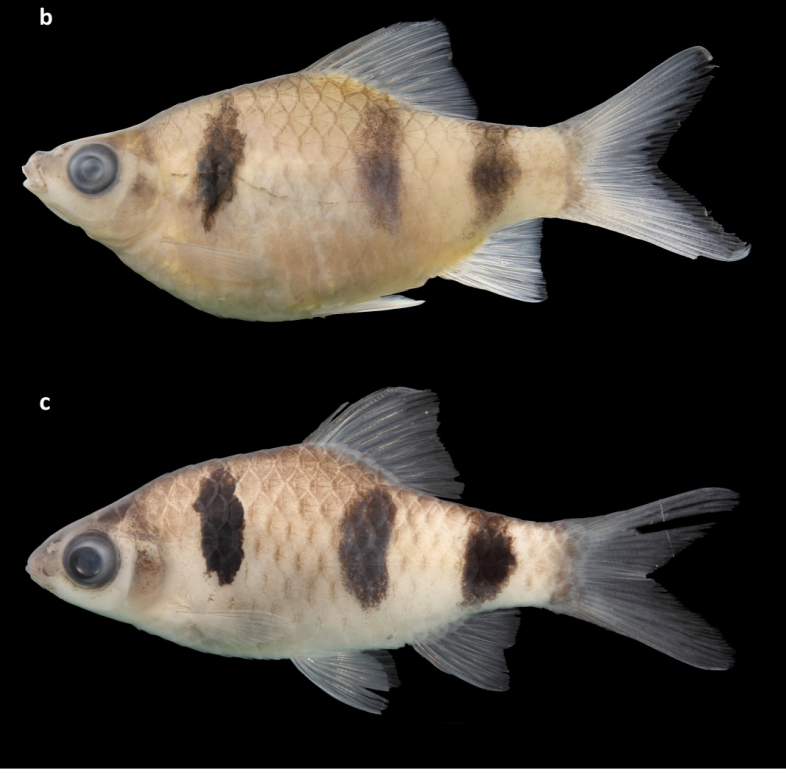

Image 3. Pethia setnai collected in the present study.

a - Male from Sanguem, Goa, b - Female from Sanguem, Goa

c - unsexed individual from Madkhol, Maharashtra. a

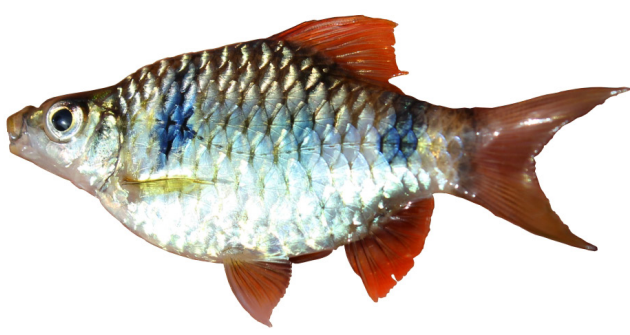

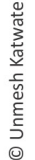

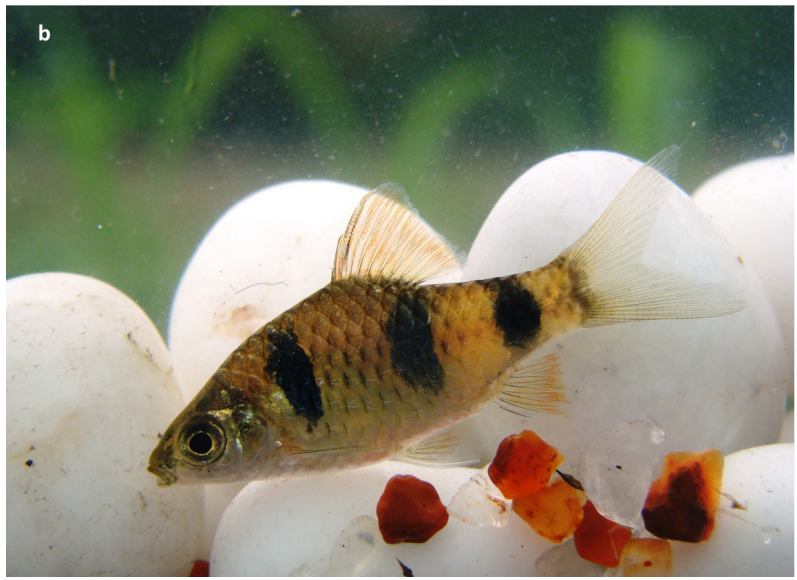

Image 4. Pethia setnai showing color in life. (a) fresh specimen from Sanguem, Goa; and (b) live specimen from Terekhol River near Madkhol, Maharashtra.

branched or laminate); post-epiphysial fontanelle absent (Image 5b); infraorbital 3 deep, partially overlapping the cheek and preoperculum (Image 5c); last unbranched dorsal-fin ray stiff, serrated (Image $5 \mathrm{~d}$ ); free uroneural absent (Image 5e); 4 supraneurals; 13 precaudal and 13 caudal vertebrae. Osteological details of $P$. setnai matches with the diagnosis of the genus Pethia provided

Table 3. Distribution of Pethia setnai. Latitude and longitude data is approximated using Google Earth from the locality details available in the references.

\begin{tabular}{|c|c|c|c|c|c|c|}
\hline State & Location & River system & Latitude $\left({ }^{0} \mathrm{~N}\right)$ & Longitude $\left({ }^{0} \mathrm{E}\right)$ & $\begin{array}{l}\text { Altitude } \\
\text { (m) }\end{array}$ & Reference \\
\hline Maharashtra & Madkhol & Terekhol & 15.94 & 73.91 & 43 & Current study \\
\hline Goa & Ponda & Zuari & 15.40 & 74.00 & 18 & Yazdani (1977) \\
\hline Goa & Sanguem & Zuari & 15.23 & 74.18 & 19 & $\begin{array}{l}\text { Chhapgar \& Sane (1992); } \\
\text { Current study }\end{array}$ \\
\hline Karnataka & Karwar & Kalinadi & 15.08 & 74.51 & 20 & Current study \\
\hline Karnataka & Karwar & Kalinadi & 15.79 & 74.58 & 20 & Current study \\
\hline Karnataka & Souparnika & Souparnika & 13.87 & 74.81 & 76 & Knight et al. (2012) \\
\hline Karnataka & Hosangadi & Varahi & 13.68 & 74.97 & 58 & Yazdani \& Ghate (1994) \\
\hline Karnataka & Agumbe & Sitanadi & 13.50 & 75.09 & 669 & Knight et al. (2012) \\
\hline Karnataka & Gundia & $\begin{array}{l}\text { Kumaradhara and } \\
\text { Nethravati river systems }\end{array}$ & 12.73 & 75.66 & 340 & Gururaja et al. (2007) \\
\hline Karnataka & $\begin{array}{l}\text { Kukke } \\
\text { Subramanya }\end{array}$ & $\begin{array}{l}\text { Kumaradhara and } \\
\text { Nethravati river systems }\end{array}$ & 12.66 & 75.61 & 126 & Knight et al. (2012) \\
\hline
\end{tabular}




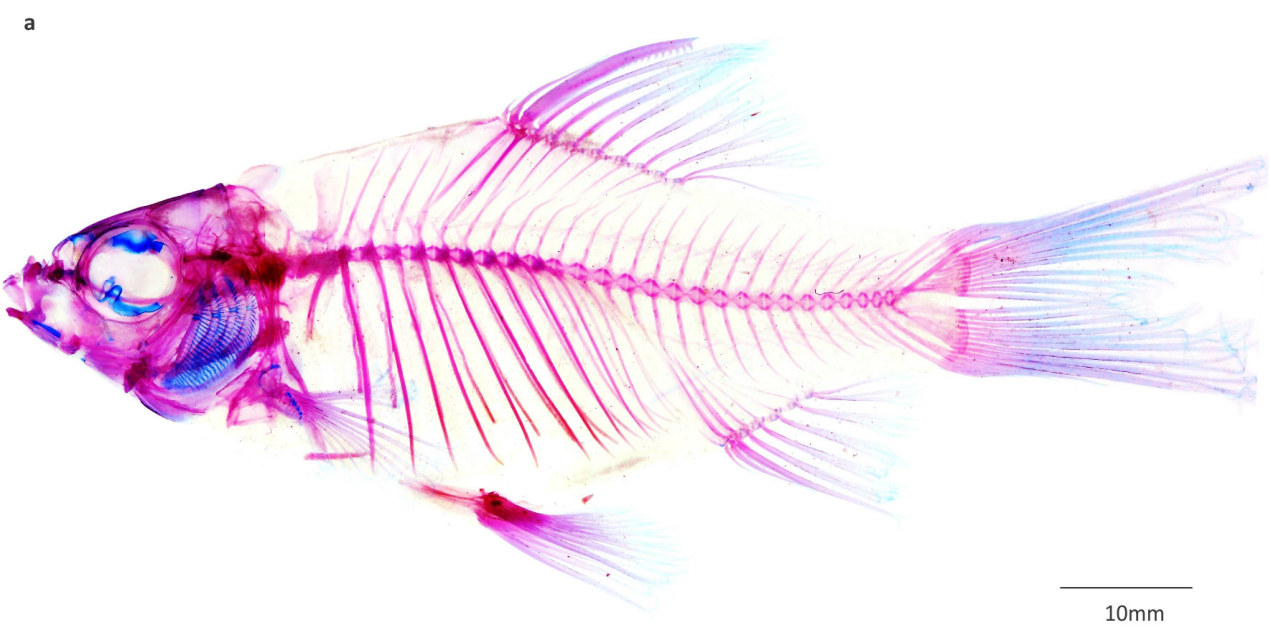

b
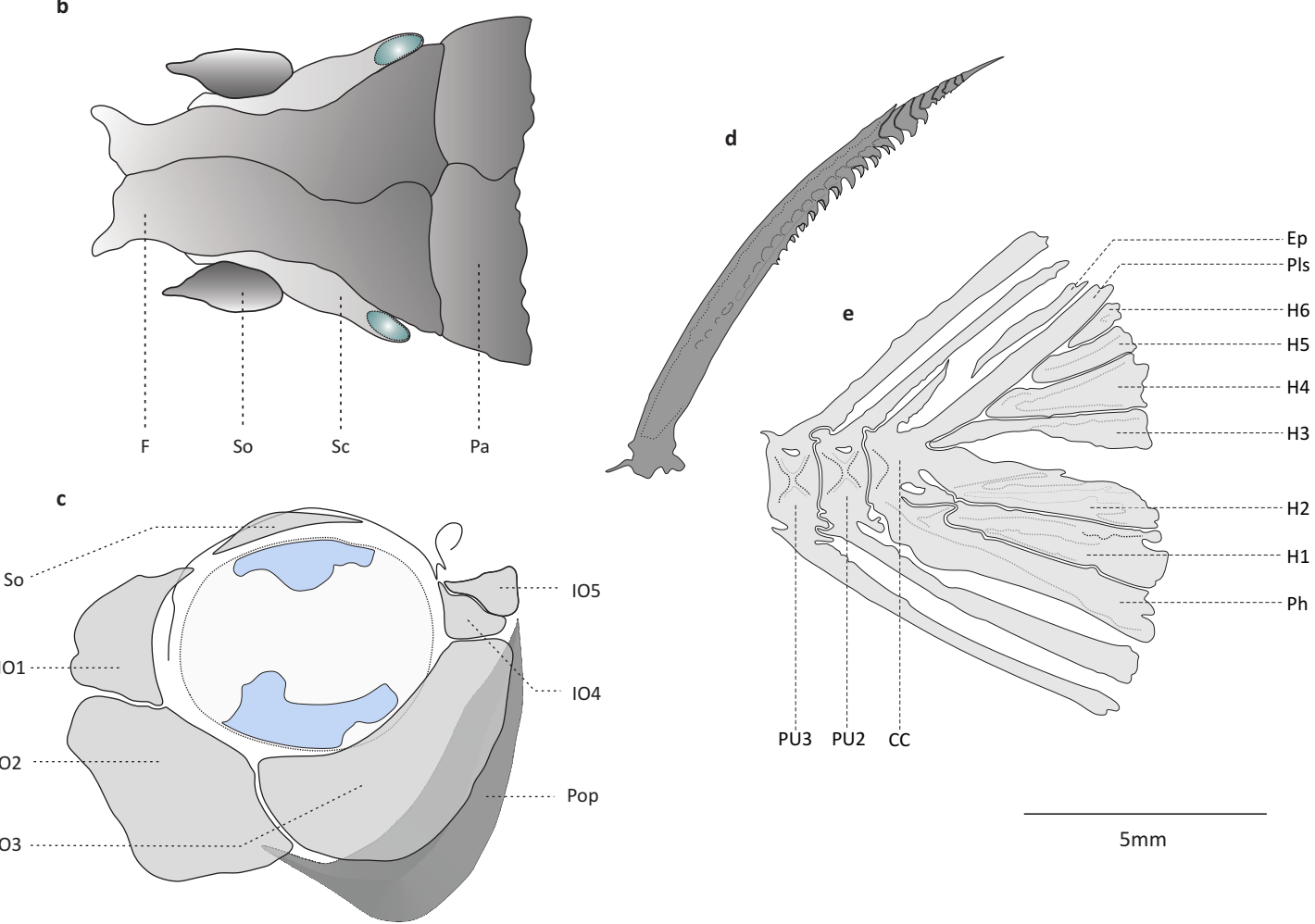

$5 \mathrm{~mm}$

Image 5. Pethia setnai topotypic material from Sanguem, Goa (BNHS FWF 70, 32.1mm SL: (a) cleared and stained specimen; (b) dorsal view of orbital region of cranium (F, frontal; Pa, parietal;; Sc, supraorbital sensory canal); (c) circumorbital series (So, supraorbital; 101-5, infraorbitals 1-5; Pop, preopercle); (d) last unbranched dorsal-fin ray and (e) caudal skeleton (CC, compound centrum; Ep, epural; H1-6, hypurals 1-6; Ph, parhypural; Pls, pleurostyle; PU2-3, preural centra 2-3). Photo credit: Unmesh Katwate.

by Pethiyagoda et al. (2012).

\section{Color variation}

In life Pethia setnai has silvery-grey or dull golden color with three black transverse bands; anterior one situated between the dorsal profile and below the lateral line encompassing 3rd and 4th lateral line scales; middle band between the posterior half of the dorsal fin base and one scale below lateral line encompassing 9th to 11th lateral line scale; posterior band between the middle of end of dorsal fin base and caudal fin and the posterior half of the anal fin base (Image 4). Posterior most and anterior most bands are darker than the middle band (Image 4a). Dorsal, ventral and anal fins are bright red in certain specimens in their natural habitat (Image 4a) but the fin colors fade rapidly in captivity (Image 4b). Some 


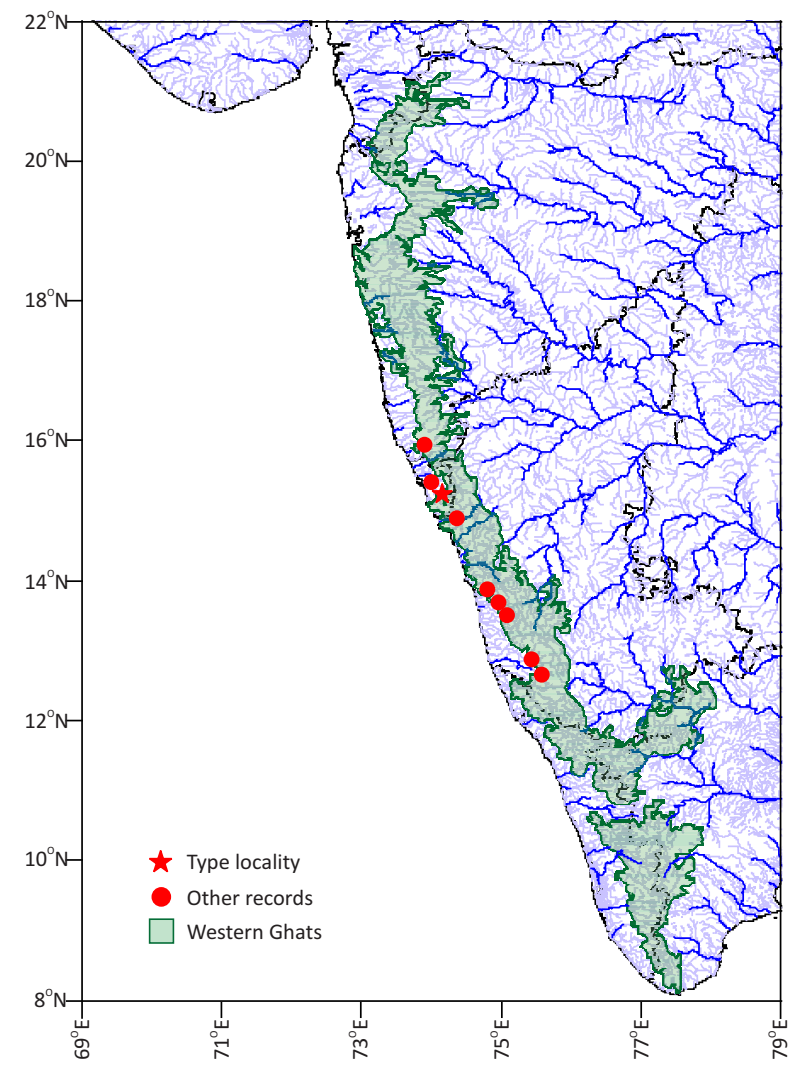

Figure 2. Distribution of Pethia setnai.

specimens have indigo blue tinge on the dorsolateral area and therefore the species is also known as indigo barb among hobbyists. While, specimens with yellow fins are also known from this species we have not come across such specimens in our study.

\section{Distribution}

Based on the current collections as well as locality information deciphered from literature (Table 3), Pethia setnai is known to be distributed in the west flowing rivers of the Western Ghats in the states of Karnataka, Goa and Maharashtra between $12.66^{\circ} \mathrm{N}$ to $15.94^{\circ} \mathrm{N}$ latitude (Fig. 2). The species is currently known from seven fragmented populations, most of them reported from lower altitudes (Table 3) except the one from Agumbe, Karnataka located at $669 \mathrm{~m}$ (Knight et al. 2012).

To our knowledge, there are no published and reliable records of Pethia setnai from the Cauvery River system, or any other east flowing rivers. Anecdotal reference to the presence of this species in the Cauvery, especially among the aquarium fish hobbyists, is as a result of the misidentification of Pethia setnai as Pethia narayani by Chhapgar \& Sane (1980). While criticizing the report of Pethia nigrofasciata from Goa by Yazdani (1977),

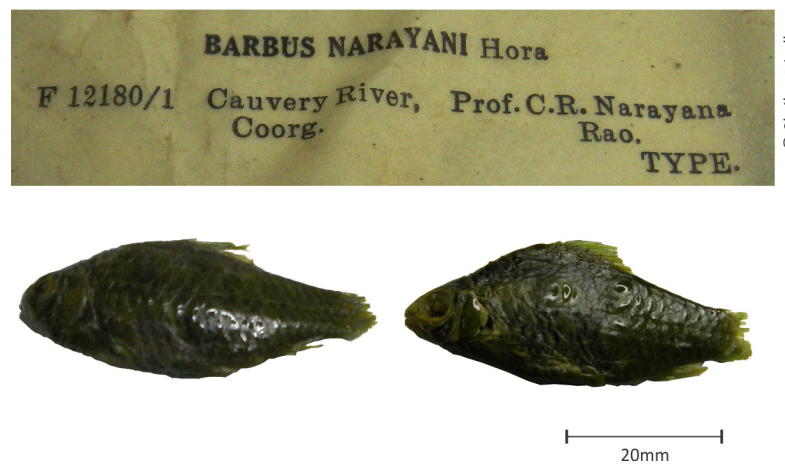

Image 6. Syntypes of Pethia narayani ZSI Kolkata F 12180/1.

Chhapgar \& Sane (1980) suggested that the species was Pethia narayani (Image 6), a species originally described from Cauvery River system in Coorg by Hora (1937). Mr. S.R. Sane who was active in the aquarium fish trade marketed the species occurring in Goa as Narayan's Barb until Chhapgar \& Sane (1992) realized that they had overlooked the presence of osseous and serrated last unbranched dorsal fin ray in the specimens from Goa (as opposed to non-osseous and non-serrated last unbranched dorsal fin ray in Pethia narayani), and described Pethia setnai (B.F. Chhapgar, pers. comm. July 2013). Apart from having strongly osseous and serrated (vs. smooth articulated) last unbranched dorsal fin ray, $P$. setnai differs from $P$. narayani based on 8 (vs. 9) branched dorsal fin rays, 5 (vs. 6) branched anal fin rays and 19-20 (vs. 22) lateral line scales. Because of the misleading common name 'Narayan's Barb' for P. setnai, it is likely that hobbyists have treated $P$. narayani from Cauvery River as $P$. setnai.

We failed to come across $P$. setnai during our repeated surveys in Mysore, Coorg and several other areas from Cauvery river system. As a result, unless a reliable report of $P$. setnai is available from Cauvery River system, backed up with genetic data, the species is considered as restricted to west flowing rivers of the Western Ghats based on Yadav (2003) and information presented in this paper.

\section{Habitat}

Chhapgar \& Sane (1992) described Pethia setnai from clear streams of Sanguem and Ponda in Goa. However, they did not provide any information on the habitat in which the species was found. As part of the present study, fresh collection of $P$. setnai was made from the Salaulim River, a tributary of Zuari River near Sanguem, Goa (Image 7). The habitat consisted of a slow flowing, clear water stream with maximum substratum composed of sand and mud. Riparian cover was rich in 


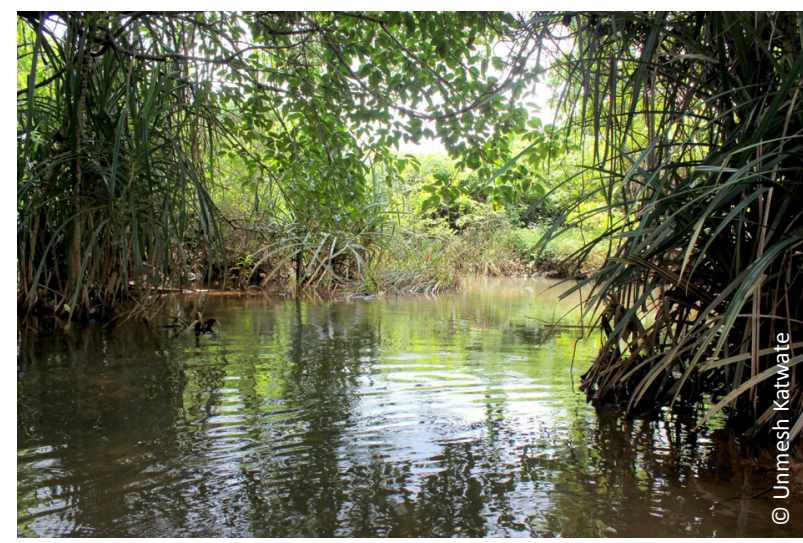

Image 7. Habitat in Zuari River near Sanguem, the type locality of Pethia setnai. [Image taken on 10.viii.2013]

vegetation, and mostly dominated by Pundanus plant species. Pethia setnai was mostly found in small shoals with 7-8 individuals in each shoal. During each collection attempt, maximum catch was dominated by females with one to two males in each shoal. Juveniles were observed to be confined at shallow depth $(0.1-0.5 \mathrm{~m})$, whereas adults were confined to greater depths (1-2 m). We also discovered a new population of $P$. setnai in the main river channel of Terekhol River at Madkhol Village (Image 8). In contrast with type locality, at Terekhol, the individuals of $P$. setnai were found in deep pools and fast flowing rapids (Image 8). Co-occurring species included Dawkinsia cf. filamentosa, Haludaria pradhani, Devario aequipinnatus, Rasbora sp. and Salmophasia sp.

\section{Threats}

Based on IUCN Categories and Criteria (IUCN 2001), Dahanukar (2011) assessed Pethia setnai as a 'Vulnerable' species owing to its restricted distribution and on-going threats to habitat because of tourism, urbanization and agricultural pollution. The Goa populations are subjected to heavy mining operations in the headwaters, apart from the pressure from increasing tourism (Image 9). Habitats of the species in Terekhol River are severely threatened by organic wastes and sewage. Further, the species is also known to occur in aquarium trade under the common name Indigo Barb (Chhapgar \& Sane 1992). Although no statistics is available on the extent of wild caught Pethia setnai in the trade, it has already been suggested that the unregulated aquarium trade is a plausible threat to the endemic and threatened species of freshwater fishes in India (Raghavan et al. 2013b). Further studies on the extent of collection and trade in $P$. setnai is therefore essential.

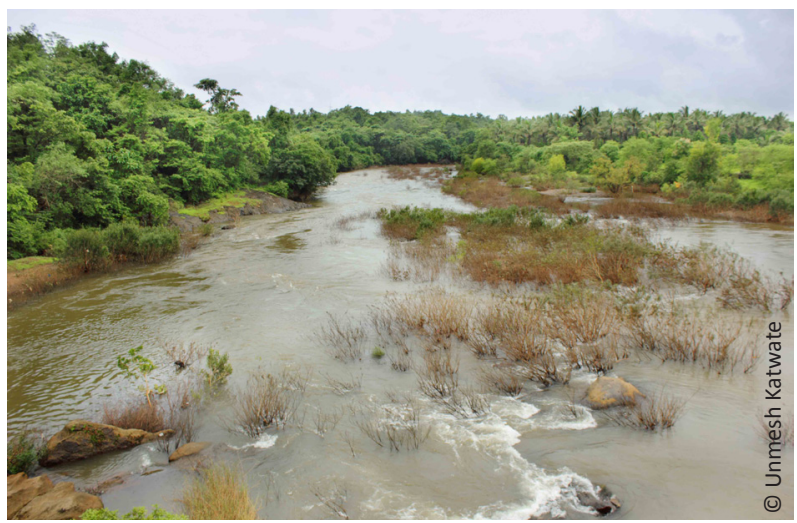

Image 8. Habitat of Pethia setnai in Terekhol River at Madkhol Village, Sindhudurga District, Maharashtra [Image taken on 12.vi.2013]

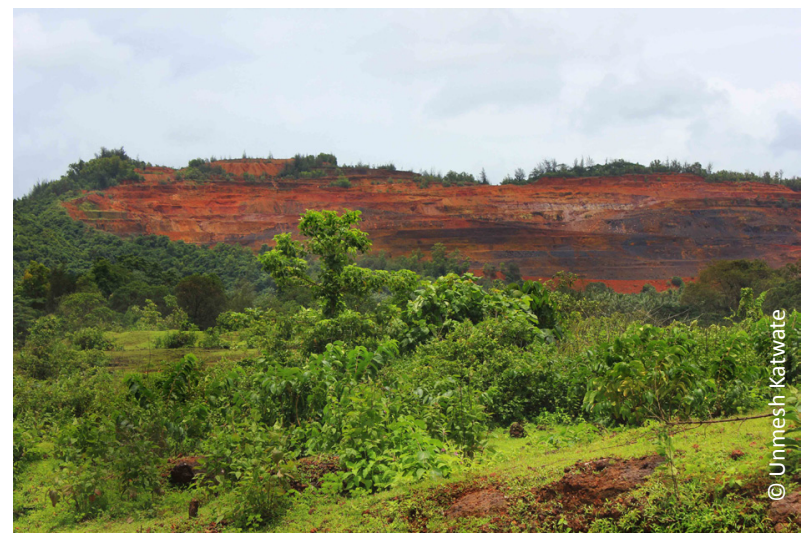

Image 9. Heavy mining operation near type locality of Pethia setnai at Sanguem, Goa. A possible threat to Pethia setnai. [Image taken on 10.viii.2013]

\section{CONCLUSIONS}

A comprehensive assessment of the status of freshwater fishes of Western Ghats for the IUCN Red List of Threatened Species revealed that little to no information exists regarding distribution, population status and life history of several threatened and endemic species (Dahanukar et al. 2011). This has led to renewed research on various aspects including taxonomic issues and those explaining detailed distribution of several threatened freshwater fishes of the Western Ghats (Ali et al. 2013a,b; Emmanuel et al. 2013; Katwate et al. 2012; Knight et al. 2013). We hope that the detailed biometric and molecular data of topotypic material of Pethia setnai will aid in the reliable identification of this threatened taxon, and the information on its distribution and threats will be helpful in directing future conservation efforts. 


\section{REFERENCES}

Ali, A., N. Dahanukar, A. Kanagavel, S. Philip \& R. Raghavan (2013a). Records of the endemic and threatened catfish, Hemibagrus punctatus from the southern Western Ghats with notes on its distribution, ecology and conservation status. Journal of Threatened Taxa 5(11): 4569-4578; http://dx.doi.org/10.11609/JoTT. 03427.4569-78

Ali, A., S. Philip \& R. Raghavan (2013b). Back from obscurity: notes on the current distribution, threats and conservation status of a poorly known cyprinid, Hypselobarbus lithopidos (Day, 1874) from the Western Ghats of India. Journal of Threatened Taxa 5(13): 47434751; http://dx.doi.org/10.11609/JoTT.o3655.4743-51

Altschul, S.F., W. Gish, W. Miller, E.W. Myers \& D.J. Lipman (1990). Basic local alignment search tool. Journal of Molecular Biology 215(3): 403-410. http://dx.doi.org/10.1016/S0022-2836(05)80360-

Bini, L.M., J.A.F. Diniz-Filho, T.F. Rangel, R.P. Bastos \& M.P. Pinto (2006) Challenging Wallacean and Linnean shortfalls: knowledge gradients and conservation planning in a biodiversity hotspot. Diversity and Distributions 12(5): 475-482. http://dx.doi.org/10.1111/j.13669516.2006.00286.x

Chen, X.L., T.Y. Chiang, H.D. Lin, H.S. Zheng, K.T. Shao, Q. Zhang \& K.C. Hsu (2007). Mitochondrial DNA phylogeography of Glyptothorax fokiensis and Glyptothorax hainanensis in Asia. Journal of Fish Biology 70: 75-93; http://dx.doi.org/10.1111/j.1095-8649.2007.01370.x

Chhapgar, B.F. \& S.R. Sane (1980). On the record of the black ruby barb, Puntius nigrofasciatus (Gunther) (Pisces:Cyprinidae) from India. Journal of Bombay Natural History Society 77: 526-527.

Chhapgar, B.F. \& S.R. Sane (1992). A new fish of the genus Puntius Hamilton (Ostariophysi: Cyprinidae) from Goa. Journal of the Bombay Natural History Society 89: 357-359.

Conway, K.W. (2011). Osteology of the South Asian genus Psilorhynchus McClelland, 1839 Teleostei: Ostariophysi: Psilorhynchidae), with investigation of its phylogenetic relationships within the order Cypriniformes. Zoological Journal of the Linnean Society 163: 150154; http://dx.doi.org/10.1111/j.1096-3642.2011.00698.x

Dahanukar, N. (2011). Puntius setnai. In: IUCN 2013. IUCN Red List of Threatened Species. Version 2013.1. <www.iucnredlist.org>. Downloaded on 10 November 2013.

Dahanukar, N., R. Raghavan, A. Ali, R. Abraham \& C.P. Shaji (2011). The status and distribution of freshwater fishes of the Western Ghats. Chapter 3, pp. 21-48. In: Molur, S., Smith, K.G., Daniel, B.A. \& Darwall, W.R.T. (compilers). The Status and Distribution of Freshwater Biodiversity in The Western Ghats, India. Cambridge, UK and IUCN, Gland, Switzerland and Zoo Outreach Organisation, Coimbatore, India 116pp.

Edgar, R.C. (2004). MUSCLE: multiple sequence alignment with high accuracy and high throughput. Nucleic Acids Research 32(5): 17921797. http://dx.doi.org/10.1093/nar/gkh340

Emmanuel, J., K. Krishnakumar, B. Pereira, A. Kanagavel, A. Ali \& R. Raghavan (2013). New records of the Endangered balitorid loach, Travancoria elongate Pethiyagoda \& Kottelat 1994, from the Kerala part of the Western Ghats, India. Journal of Threatened Taxa 5(10): 4504-4509; http://dx.doi.org/10.11609/JoTT.03407.4504-9

Gururaja, K.V., Sreekantha, S. Ali, G.R. Rao, V.D. Mukri \& T.V. Ramachandra (2007). Biodiversity and ecological significance of Gundia river catchment. http://www.ces.iisc.ernet.in/biodiversity/ pubs/ces_tr/TR-116/Gundia\%20Flora\%20and\%20fauna\%20 report_31may07_REV.pdf

Hora, S.L. (1937). Notes on fishes in the Indian Museum. XXVIII. On three collections of fish from Mysore and Coorg, south India. Records of the Indian Museum 39 (1): 5-28.

IUCN (2008). 'IUCN Policy Statement on Research Involving Species at Risk of Extinction'.http://intranet.iucn.org/webfiles/doc/ IUCNPolicy/Resolutions/2008_WCC_4/English/RES/res_4_105_ guidelines_regarding_research_and_scientific_collecting_of_ threatened_species.pdf; accessed on 30 December 2011.
Katwate, U., R. Raut, M. Khot, M. Paingankar \& N. Dahanukar (2012). Molecular identification and ecology of a newly discovered population of sun catfish Horabagrus brachysoma from northern Western Ghats of India. ISRN Zoology 2012: 419320; http://dx.doi. org/10.5402/2012/419320

Knight, J.D.M., K.R. Devi, T.J. Indra \& M. Arunachalam (2012). A new species of barb Puntius nigripinnis (Teleostei: Cyprinidae) from southern Western Ghats, India. Journal of Threatened Taxa 4(3): 2409-2416; http://dx.doi.org/10.11609/JoTT.o3014.2409-16

Knight, J.D.M., A. Rai \& R.K.P. D'souza (2013). Re-description of Hypselobarbus lithopidos (Teleostei: Cyprinidae), based on its rediscovery from the Western Ghats, India, with notes on $H$. thomassi. Journal of Threatened Taxa 5(13): 4734-4742; http:// dx.doi.org/10.11609/JoTT.o3602.4734-42

Kullander, S.O. (2008). Five new species of Puntius from Myanmar (Teleostei: Cyprinidae). Ichthyological Exploration of Freshwaters 19(1): 59-84.

Pethiyagoda, R., M. Meegaskumbura \& K. Maduwage (2012). A synopsis of the South Asian fishes referred to Puntius (Pisces: Cyprinidae). Ichthyological Exploration of Freshwaters 23(1): 69-95.

Posada, D. \& K.A. Crandall (2001). Selecting the best-fit model of nucleotide substitution. Systems Biology 50(4): 580-601; http:// dx.doi.org/10.1080/10635150118469

Potthoff, T. (1984). Clearing and staining techniques, pp. 35-37. In: Moser, H.G., W.J. Richards, D.M. Cohen, M.P. Fahay, A.W. Kendall, Jr. \& S.L. Richardson (eds.). Ontogeny and Systematics of Fishes. American Society for Ichthyology and Herpetology, Special Publication No. 1., 760pp.

Raghavan, R., N. Dahanukar, K. Krishnakumar, A. Ali, S. Solomon, M.R. Ramprasanth, F. Baby, B. Pereira, J. Tharian \& S. Philip (2012). Western Ghats fish fauna in peril: are pseudo conservationist attitudes to be blamed? Current Science 102(6): 835-837.

Raghavan, R., S. Philip, A. Ali \& N. Dahanukar (2013a). Sahyadria, a new genus of barbs (Teleostei: Cyprinidae) from Western Ghats of India. Journal of Threatened Taxa 5(15): 4932-4938; http://dx.doi. org/10.11609/JoTT.o3673.4932-8.

Raghavan, R., N. Dahanukar, M. Tlusty, A. Rhyne, K.K. Kumar, S. Molur \& A.M. Rosser (2013b). Uncovering an obscure trade: threatened freshwater fishes and the aquarium pet markets. Biological Conservation 164: 158-169; http://dx.doi.org/10.1016/j. biocon.2013.04.019

Tamura, K. \& M. Nei (1993). Estimation of the number of nucleotide substitutions in the control region of mitochondrial DNA in humans and chimpanzees. Molecular Biology and Evolution 10: 512-526.

Tamura, K., D. Peterson, N. Peterson, G. Stecher, M. Nei \& S. Kumar (2011). MEGA5: Molecular Evolutionary Genetics Analysis using Maximum Likelihood, Evolutionary Distance, and Maximum Parsimony Methods. Molecular Biology and Evolution 28: 27312739; http://dx.doi.org/10.1093/molbev/msr121

Yadav, B.E. (2003). Ichthyofauna of northern part of Western Ghats. Zoological Survey of India, Occasional Paper 215: 1-39.

Yazdani, G.M. \& H.V. Ghate (1994). On Puntius setnai Chhapgar and Sane: new reports and comments. Journal of the Bombay Natural History Society 91: 464-465.

Yazdani, G.M. (1977). On a new record of black ruby, Puntius nigrofasciatus (Gunther) from India (Cypriniformes: Cyprinidae). Current Science 46: 760. 
Appendix A. Morphometry of specimens collected from Terekhol River at Madkhol.

\begin{tabular}{|c|c|c|c|c|c|c|c|c|c|c|c|c|}
\hline Characters & $\begin{array}{c}\text { BNHS } \\
\text { FWF } \\
55\end{array}$ & $\begin{array}{c}\text { BNHS } \\
\text { FWF } \\
56\end{array}$ & $\begin{array}{c}\text { BNHS } \\
\text { FWF } \\
57\end{array}$ & $\begin{array}{c}\text { BNHS } \\
\text { FWF } \\
58\end{array}$ & $\begin{array}{c}\text { BNHS } \\
\text { FWF } \\
59\end{array}$ & $\begin{array}{c}\text { BNHS } \\
\text { FWF } \\
60\end{array}$ & $\begin{array}{c}\text { BNHS } \\
\text { FWF } \\
61\end{array}$ & $\begin{array}{c}\text { BNHS } \\
\text { FWF } \\
62\end{array}$ & $\begin{array}{c}\text { WILD- } \\
13- \\
\text { PIS- } \\
047\end{array}$ & $\begin{array}{c}\text { WILD- } \\
13- \\
\text { PIS- } \\
048\end{array}$ & $\begin{array}{c}\text { ZSI- } \\
\text { WRC } \\
\text { P/3568 }\end{array}$ & $\begin{array}{c}\text { ZSI- } \\
\text { WRC } \\
\text { P/3568 }\end{array}$ \\
\hline Total Length (mm) & 42.20 & 32.17 & 30.30 & 32.74 & 26.15 & 27.53 & 25.18 & 25.10 & 30.47 & 29.11 & 29.13 & 26.56 \\
\hline Standard Length $(\mathrm{mm})$ & 32.44 & 25.34 & 23.79 & 25.20 & 20.37 & 20.94 & 19.17 & 19.79 & 23.81 & 22.26 & 22.63 & 20.15 \\
\hline Head length (mm) & 8.97 & 7.48 & 6.91 & 7.11 & 6.01 & 6.09 & 5.95 & 5.94 & 7.12 & 6.42 & 6.85 & 5.83 \\
\hline Head depth (mm) & 7.46 & 6.07 & 5.73 & 6.16 & 5.46 & 5.27 & 4.88 & 4.62 & 5.94 & 5.82 & 5.52 & 4.76 \\
\hline Head width $(\mathrm{mm})$ & 5.43 & 4.10 & 3.80 & 4.22 & 3.41 & 3.54 & 3.21 & 3.25 & 3.87 & 3.68 & 3.53 & 3.36 \\
\hline Snout length $(\mathrm{mm})$ & 2.55 & 1.93 & 1.73 & 2.01 & 1.64 & 1.82 & 1.54 & 2.00 & 1.98 & 1.78 & 1.96 & 1.74 \\
\hline Eye diameter (mm) & 3.22 & 2.65 & 2.50 & 2.67 & 2.04 & 2.25 & 1.88 & 1.61 & 2.38 & 2.18 & 2.14 & 2.09 \\
\hline Inter orbital width (mm) & 2.45 & 2.21 & 1.81 & 2.40 & 1.90 & 2.18 & 1.77 & 1.58 & 2.02 & 2.03 & 2.07 & 1.83 \\
\hline Body depth (mm) & 12.51 & 9.12 & 8.23 & 9.20 & 7.04 & 7.18 & 6.92 & 6.73 & 7.96 & 8.07 & 7.94 & 6.98 \\
\hline $\begin{array}{l}\text { Body width at dorsal fin origin } \\
(\mathrm{mm})\end{array}$ & 5.89 & 4.14 & 3.90 & 4.32 & 3.35 & 3.45 & 2.42 & 2.68 & 3.73 & 3.80 & 3.53 & 3.35 \\
\hline $\begin{array}{l}\text { Body width at anal fin origin } \\
(\mathrm{mm})\end{array}$ & 4.83 & 3.08 & 2.84 & 3.23 & 2.57 & 2.64 & 2.15 & 2.26 & 2.93 & 2.84 & 2.80 & 2.52 \\
\hline Pre dorsal distance $(\mathrm{mm})$ & 16.58 & 13.07 & 12.07 & 12.62 & 10.53 & 10.88 & 10.85 & 10.48 & 11.87 & 11.8 & 12.05 & 10.26 \\
\hline $\begin{array}{l}\text { Dorsal to hypural distance } \\
(\mathrm{mm})\end{array}$ & 15.97 & 12.64 & 11.67 & 12.54 & 9.93 & 9.78 & 8.26 & 8.99 & 11.02 & 10.66 & 10.68 & 9.97 \\
\hline Prepelvic distance (mm) & 16.02 & 12.83 & 12.33 & 12.86 & 11.19 & 11.09 & 11.01 & 10.72 & 12.56 & 11.26 & 12.41 & 10.41 \\
\hline Preanal distance $(\mathrm{mm})$ & 23.55 & 18.32 & 16.75 & 17.71 & 14.38 & 15.53 & 13.94 & 14.6 & 16.59 & 15.41 & 16.40 & 14.11 \\
\hline Prepectoral distance $(\mathrm{mm})$ & 9.46 & 8.10 & 7.23 & 7.84 & 6.27 & 6.74 & 6.43 & 6.68 & 7.42 & 6.90 & 7.21 & 6.22 \\
\hline Dorsal fin length $(\mathrm{mm})$ & 8.21 & 6.87 & 6.23 & 6.89 & 5.46 & 5.61 & 4.56 & 5.30 & 5.75 & 5.80 & 5.84 & 5.49 \\
\hline Dorsal fin spine length ( $\mathrm{mm}$ ) & 5.88 & 4.57 & 3.74 & 4.72 & 3.46 & 3.54 & 3.62 & 3.22 & 4.13 & 3.86 & 4.28 & 3.58 \\
\hline $\begin{array}{l}\text { Length of dorsal fin base } \\
(\mathrm{mm})\end{array}$ & 6.14 & 4.97 & 4.28 & 4.86 & 3.21 & 3.62 & 2.33 & 2.38 & 4.20 & 4.08 & 4.03 & 3.27 \\
\hline Pectoral fin length (mm) & 6.93 & 5.03 & 4.37 & 4.95 & 3.63 & 3.84 & 3.32 & 3.27 & 4.31 & 3.82 & 3.94 & 3.70 \\
\hline Anal fin depth (mm) & 6.23 & 5.14 & 4.33 & 5.11 & 3.73 & 3.76 & 3.31 & 3.39 & 4.21 & 4.18 & 4.23 & 3.80 \\
\hline Caudal peduncle length (mm) & 6.47 & 4.64 & 4.53 & 4.85 & 4.06 & 4.09 & 4.02 & 3.74 & 4.42 & 4.16 & 4.15 & 4.01 \\
\hline Caudal peduncle depth (mm) & 4.92 & 3.84 & 3.64 & 3.87 & 2.97 & 3.15 & 2.71 & 2.35 & 3.51 & 3.41 & 3.29 & 2.91 \\
\hline
\end{tabular}


Appendix B. Morphometry of specimens collected from Sanguem, Goa.

\begin{tabular}{|c|c|c|c|c|c|c|c|c|c|c|c|c|}
\hline Characters & $\begin{array}{l}\text { BNHS } \\
\text { FWF } 63\end{array}$ & $\begin{array}{l}\text { BNHS } \\
\text { FWF } 64\end{array}$ & $\begin{array}{l}\text { BNHS } \\
\text { FWF } 65\end{array}$ & $\begin{array}{l}\text { BNHS } \\
\text { FWF } 66\end{array}$ & $\begin{array}{l}\text { BNHS } \\
\text { FWF } 67\end{array}$ & $\begin{array}{l}\text { BNHS } \\
\text { FWF } 68\end{array}$ & $\begin{array}{l}\text { BNHS } \\
\text { FWF } 69\end{array}$ & $\begin{array}{l}\text { BNHS } \\
\text { FWF } 70\end{array}$ & $\begin{array}{c}\text { WILD- } \\
13- \\
\text { PIS-044 }\end{array}$ & $\begin{array}{c}\text { WILD- } \\
13- \\
\text { PIS-045 }\end{array}$ & $\begin{array}{c}\text { ZSI- } \\
\text { WRC } \\
P / 3567\end{array}$ & $\begin{array}{c}\text { ZSI- } \\
\text { WRC } \\
\text { P/3567 }\end{array}$ \\
\hline Total Length (mm) & 50.38 & 50.42 & 45.14 & 42.80 & 36.51 & 35.63 & 37.85 & 40.65 & 49.96 & 39.04 & 45.85 & 33.99 \\
\hline Standard Length (mm) & 39.29 & 39.66 & 34.32 & 32.25 & 27.90 & 27.18 & 29.13 & 31.20 & 38.69 & 29.82 & 35.14 & 26.30 \\
\hline Head length (mm) & 10.90 & 12.04 & 10.08 & 9.97 & 8.06 & 7.87 & 9.06 & 9.47 & 11.14 & 9.03 & 10.53 & 8.53 \\
\hline Head depth (mm) & 10.05 & 10.09 & 8.29 & 7.81 & 6.90 & 6.63 & 7.25 & 7.95 & 9.81 & 7.02 & 8.73 & 5.96 \\
\hline Head width (mm) & 6.36 & 6.31 & 5.33 & 4.77 & 4.34 & 4.33 & 4.47 & 5.18 & 6.29 & 4.74 & 5.61 & 4.00 \\
\hline Snout length (mm) & 3.54 & 3.65 & 2.87 & 2.94 & 2.34 & 2.38 & 3.05 & 2.39 & 3.29 & 2.63 & 3.31 & 2.44 \\
\hline Eye diameter (mm) & 3.26 & 3.40 & 2.97 & 2.92 & 2.41 & 2.64 & 2.42 & 3.51 & 3.20 & 2.84 & 3.10 & 2.42 \\
\hline $\begin{array}{l}\text { Inter orbital width } \\
(\mathrm{mm})\end{array}$ & 3.93 & 3.99 & 3.53 & 3.50 & 3.06 & 3.12 & 3.05 & 2.05 & 3.92 & 3.23 & 3.80 & 2.83 \\
\hline Body depth (mm) & 17.34 & 17.61 & 14.19 & 12.98 & 10.91 & 11.11 & 10.78 & 11.17 & 16.72 & 11.69 & 15.36 & 9.62 \\
\hline $\begin{array}{l}\text { Body width at dorsal } \\
\text { fin origin }(\mathrm{mm})\end{array}$ & 6.95 & 7.01 & 5.62 & 4.94 & 4.90 & 4.31 & 4.44 & 4.88 & 6.85 & 4.74 & 5.97 & 3.83 \\
\hline $\begin{array}{l}\text { Body width at anal fin } \\
\text { origin }(\mathrm{mm})\end{array}$ & 4.90 & 4.95 & 4.12 & 3.89 & 3.17 & 3.32 & 3.40 & 3.09 & 4.82 & 3.69 & 4.37 & 2.88 \\
\hline $\begin{array}{l}\text { Pre dorsal distance } \\
(\mathrm{mm})\end{array}$ & 20.48 & 21.73 & 17.60 & 17.32 & 14.59 & 14.80 & 15.12 & 14.69 & 20.25 & 15.60 & 18.92 & 14.01 \\
\hline $\begin{array}{l}\text { Dorsal to hypural } \\
\text { distance }(\mathrm{mm})\end{array}$ & 18.91 & 18.41 & 16.53 & 14.91 & 13.99 & 13.06 & 13.94 & 13.49 & 18.27 & 14.26 & 16.66 & 12.57 \\
\hline $\begin{array}{l}\text { Prepelvic distance } \\
(\mathrm{mm})\end{array}$ & 19.10 & 20.72 & 17.11 & 16.54 & 14.1 & 13.43 & 15.41 & 13.50 & 18.79 & 14.99 & 17.92 & 14.17 \\
\hline Preanal distance (mm) & 27.98 & 29.28 & 24.59 & 24.24 & 19.83 & 19.36 & 21.41 & 20.81 & 28.05 & 20.90 & 25.99 & 20.07 \\
\hline $\begin{array}{l}\text { Prepectoral distance } \\
(\mathrm{mm})\end{array}$ & 10.04 & 11.90 & 9.76 & 9.79 & 7.87 & 7.45 & 8.53 & 8.76 & 10.42 & 8.88 & 10.13 & 7.42 \\
\hline Dorsal fin length (mm) & 10.40 & 10.43 & 8.54 & 9.72 & 7.36 & 7.85 & 7.92 & 7.52 & 10.12 & 8.31 & 9.62 & 6.62 \\
\hline $\begin{array}{l}\text { Dorsal fin spine length } \\
(\mathrm{mm})\end{array}$ & 7.66 & 7.62 & 5.98 & 6.65 & 5.28 & 5.18 & 5.74 & 5.24 & 7.13 & 5.62 & 6.77 & 5.16 \\
\hline $\begin{array}{l}\text { Length of dorsal fin } \\
\text { base }(\mathrm{mm})\end{array}$ & 7.55 & 7.52 & 6.45 & 6.55 & 5.31 & 5.07 & 4.81 & 5.19 & 7.43 & 5.81 & 7.12 & 4.28 \\
\hline $\begin{array}{l}\text { Pectoral fin length } \\
(\mathrm{mm})\end{array}$ & 7.93 & 8.75 & 7.27 & 7.09 & 6.42 & 6.24 & 6.17 & 3.13 & 7.90 & 6.47 & 8.27 & 5.30 \\
\hline Anal fin depth (mm) & 7.43 & 6.58 & 6.63 & 6.98 & 5.42 & 5.33 & 5.16 & 4.73 & 7.44 & 6.21 & 7.04 & 4.65 \\
\hline $\begin{array}{l}\text { Caudal peduncle } \\
\text { length }(\mathrm{mm})\end{array}$ & 6.26 & 6.62 & 5.96 & 5.82 & 5.27 & 4.94 & 5.80 & 5.10 & 6.02 & 5.81 & 6.14 & 4.55 \\
\hline $\begin{array}{l}\text { Caudal peduncle } \\
\text { depth }(\mathrm{mm})\end{array}$ & 5.96 & 6.09 & 5.32 & 4.92 & 4.18 & 4.03 & 4.19 & 4.62 & 5.83 & 4.46 & 5.43 & 3.82 \\
\hline
\end{tabular}


Appendix C. Morphometry of specimens collected from Karwar, Karnataka.

\begin{tabular}{|c|c|c|c|c|}
\hline Characters & $\begin{array}{l}\text { ZSI-WRC } \\
\text { P/3572 }\end{array}$ & $\begin{array}{c}\text { ZSI-WRC } \\
\text { P/3571 }\end{array}$ & $\begin{array}{c}\text { ZSI-WRC } \\
\text { P/3571 }\end{array}$ & $\begin{array}{c}\text { ZSI-WRC } \\
\text { P/3571 }\end{array}$ \\
\hline Total Length (mm) & $\begin{array}{c}\text { Caudal } \\
\text { fin } \\
\text { damaged }\end{array}$ & $\begin{array}{c}\text { Caudal } \\
\text { fin } \\
\text { damaged }\end{array}$ & $\begin{array}{c}\text { Caudal } \\
\text { fin } \\
\text { damaged }\end{array}$ & $\begin{array}{c}\text { Caudal } \\
\text { fin } \\
\text { damaged }\end{array}$ \\
\hline $\begin{array}{l}\text { Standard Length } \\
(\mathrm{mm})\end{array}$ & 37.28 & 36.1 & 31.76 & 30.73 \\
\hline Head length $(\mathrm{mm})$ & 11.33 & 11.95 & 8.95 & 8.68 \\
\hline Head depth $(\mathrm{mm})$ & 8.16 & 7.92 & 7.47 & 7.31 \\
\hline Head width (mm) & 5.97 & 5.97 & 5.23 & 5 \\
\hline Snout length (mm) & 4.01 & 4.03 & 2.84 & 2.6 \\
\hline Eye diameter (mm) & 3.32 & 3.43 & 3.1 & 2.65 \\
\hline $\begin{array}{l}\text { Inter orbital width } \\
(\mathrm{mm})\end{array}$ & 4.08 & 4.05 & 3.72 & 3.17 \\
\hline Body depth (mm) & 15.66 & 14.6 & 13.42 & 12.01 \\
\hline $\begin{array}{l}\text { Body width at dorsal } \\
\text { fin origin }(\mathrm{mm})\end{array}$ & 5.55 & 4.93 & 4.73 & 4.45 \\
\hline $\begin{array}{l}\text { Body width at anal fin } \\
\text { origin }(\mathrm{mm})\end{array}$ & 3.11 & 3.38 & 3.16 & 2.65 \\
\hline $\begin{array}{l}\text { Pre dorsal distance } \\
(\mathrm{mm})\end{array}$ & 19.94 & 20 & 16.54 & 14.16 \\
\hline $\begin{array}{l}\text { Dorsal to hypural } \\
\text { distance }(\mathrm{mm})\end{array}$ & 20.51 & 17.6 & 16.22 & 16.57 \\
\hline $\begin{array}{l}\text { Prepelvic distance } \\
(\mathrm{mm})\end{array}$ & 18.12 & 18.25 & 15.38 & 14.49 \\
\hline $\begin{array}{l}\text { Preanal distance } \\
(\mathrm{mm})\end{array}$ & 26.8 & 26.21 & 22.18 & 21.46 \\
\hline $\begin{array}{l}\text { Prepectoral distance } \\
(\mathrm{mm})\end{array}$ & 11.75 & 12.23 & 10 & 8.68 \\
\hline $\begin{array}{l}\text { Dorsal fin length } \\
(\mathrm{mm})\end{array}$ & 9.23 & 10.76 & 8.75 & damaged \\
\hline $\begin{array}{l}\text { Dorsal fin spine } \\
\text { length }(\mathrm{mm})\end{array}$ & 5.96 & 6.69 & 6.44 & damaged \\
\hline $\begin{array}{l}\text { Length of dorsal fin } \\
\text { base }(\mathrm{mm})\end{array}$ & 6.47 & 6.71 & 6.42 & 6.24 \\
\hline $\begin{array}{l}\text { Pectoral fin length } \\
(\mathrm{mm})\end{array}$ & 7.16 & 7.52 & 8.58 & 6.28 \\
\hline Anal fin depth (mm) & 7.1 & 6.98 & 5.92 & 6.55 \\
\hline $\begin{array}{l}\text { Caudal peduncle } \\
\text { length }(\mathrm{mm})\end{array}$ & 5.6 & 6.34 & 5.1 & 4.67 \\
\hline $\begin{array}{l}\text { Caudal peduncle } \\
\text { depth }(\mathrm{mm})\end{array}$ & 5.78 & 5.69 & 5.15 & 5.14 \\
\hline
\end{tabular}
currently working as Scientist-A in BNHS. He works on conservation, taxonomy and ecological aspects of freshwater fishes and amphibians of the Western Ghats. MANDAR S. PAINGANKAR is a molecular biologist and works on vector biology with an emphasis on host parasite interactions. He works on molecular phylogeny and systematics of freshwater fishes as a hobby. SHRIKANT JADHAV is a scientist in Zoological Survey of India. He works on freshwater fish diversity and taxonomy. NeElesh DaHANUKAR works in ecology and evolution with an emphasis on mathematical and statistical analysis. He is also interested in taxonomy, distribution patterns and molecular phylogeny of freshwater fish and amphibians.

Acknowledgements: We are grateful to Abhijeet Gharat, Pratik, Keerthi Krutha, Shreya Mulherkar, Saahil Acharya and Nikhil Modak for helping with the collections. We thank Chetana Katwate for help in osteology and morphometric study. We thank Dr. Siby Philip for help with the phylogenetic analysis and Dr. B.F. Chhapgar for helpful discussions. We are grateful to Dr. Asad Rahmani, Director; Dr. Deepak Apte, COO: Rahul Khot, incharge Natural History Collection department and Vithoba Hegde, senior field assistant, for their help during study of the museum specimens and registration of specimens in Bombay Natural History Society (BNHS), Mumbai. We are also grateful to Dr. Sanjay Molur, Founder Secretary; and Priyanka lyer, curator of fish collection, for holding our specimen vouchers in the museum collection of Wildlife Information Liaison Development (WILD) Society, Coimbatore. We thank the Director and Officer In-Charge (Collections), Zoological Survey of India (ZSI), Kolkata for providing us the access to the type material of the species. We are also thankful to Dr. Pankaj Bhatnagar, Officer-in-charge, Zoological Survey of India, Western Regional Center, Pune, for encouragement and support. 